Acta medico-historica Rigensia (2020) XIII: 07-08

doi:10.25143/amhr.2020.XIII.01

REDAKCIJAS SLEJA

\title{
Medicīnas vēsture un medicīnas vēsturnieki pandēmijas laikā
}

Acta medico-historica Rigensia XIII sējums ir kārtējais šī enciklopēdiskā izdevuma 32 grāmatu vēsturē. Pirmo reizi izdevuma sešdesmit gadu pastāvēšanas laikā tā slejās parādās akronīms COVID-19. Likumsakarīgi, jo pandēmija kḷuva ne vien par dominējušo 2020. gada notikumu visā pasaulē, bet arī par izaicinājumu medicīnas vēsturniekiem. Pavasar̄̄ strauji pieauga mediju interese par epidēmiju un pandēmiju vēsturi, tika meklētas vēsturiskos piemēros balstītas mācības un spriests par jauniem koppētījumu virzieniem.

Mūsu izdevuma redkolēgijas biedru uzrunāja Oxford University Press izdevniecības žurnāla Journal of the History of Medicine and Allied Sciences redaktore Laura Hiršbeina (Laura Hirshbein), aicinot anonīmi recenzēt Latvijas pētnieka rakstu par epidēmijām Latvijas teritorijā 20. gadsimta sākumā. Visā pasaulē pieauga interese par infekcijas slimību izplatības vēsturiskiem pētījumiem, un Starptautiskās medicīnas vēsturnieku biedrības prezidents, profesors Karlos Veska (Carlos Viesca), nāca klajā ar aicinājumu savas biedrības biedriem fiksēt mūsdienu epidemioloǵisko ainu un faktus vienā konkrētā dienā visā pasaulē, proti, 2020. gada 7. aprīlī Starptautiskajā veselības dienā.

COVID-19 iekḷūs pasaules medicīnas vēstures kanonos kā pirmā slimība, kuras izplatībai un upuru statistikai mūsdienu mediju un tehnoloǵiju pasaulē ik dienu varēja sekot ikviens no mums. Ziṇu pārpilnība un skaitlu dažādā interpretācija ḷāva novērot arī jaunās slimības monitorēšanas paradigmas ietekmi uz sabiedrības garīgo veselību.

Pandēmija būtiski koriǵēja ne vien medicīnas vēstures pētījumu fokusu, bet ar̄̄ 2020. gadā plānoto zīmīgāko medicīnas vēstures notikumu norises formātu un laiku. Starp tādiem bija Paula Stradiṇa balvas pasniegšana, kas pirmo reizi vēsturē epidemioloǵisku ierobežojumu dēḷ notika 
ārpus Paula Stradiṇa Medicīnas vēstures muzeja telpām, un 47. Starptautiskās medicīnas vēsturnieku biedrības kongress, kas pirmo reizi vēsturē tika atklāts virtuāli. Par to plašāk stāstīts žurnāla sadaḷā "Akadēmiskā un muzeju dzīve".

Hibrīdformātā - daḷēji klātienē un daḷēji tiešsaistē - noritēja Rīgas Stradiṇa universitātes Medicīnas vēstures institūta organizētais simpozijs "Politizētā medicīna Austrumeiropas diktatūrās", Rīgā tiekoties pētniekiem no Latvijas, Lietuvas, Igaunijas, Polijas un Vācijas. Projektā iesaistīto medicīnas vēsturnieku raksti ar ekspertu komentāriem līdzās citiem pētījumiem lasāmi Acta medico-historica Rigensia XIII sējuma pētniecisko rakstu sadaḷā. Arī šajā krājumā sniegts Latvijā, un ne tikai, medicīnas vēsturē izdotu grāmatu apskats.

Sākot ar Acta medico-historica Rigensia XI (2018) sējumu, tika nolemts virzīt RSU Medicīnas vēstures institūta un Paula Stradiṇa Medicīnas vēstures muzeja kopizdevumu indeksēto akadēmisko žurnālu datubāzēs. Mērķtiecīgs un precīzs redakcijas kolēǵijas darbs, nodrošinot Acta medico-historica Rigensia iznākšanas regularitāti un starptautiskumu trīs gadu garumā, bija priekšnoteikums, kura veiksmīga īstenošana paver iespēju nākošajam žurnāla attīstības posmam un ḷauj cerīgi lūkoties Acta medico-historica Rigensia nākotnē.

Juris Salaks, Ieva Lībiete 